\title{
Do born global SMEs reap more benefits from ICT use than other internationalizing small firms?
}

DOI:

$10.4337 / 9780857938046.00021$

\section{Document Version}

Accepted author manuscript

Link to publication record in Manchester Research Explorer

\section{Citation for published version (APA):}

Sinkovics, N., Pezderka, N., Sinkovics, R. R., \& Jean, R. J. B. (2012). Do born global SMEs reap more benefits from ICT use than other internationalizing small firms? In M. Gabrielsson, \& V. H. M. Kirpalani (Eds.), Handbook of Research on Born Globals (pp. 185-213). Edward Elgar Publishing Ltd.

https://doi.org/10.4337/9780857938046.00021

\section{Published in:}

Handbook of Research on Born Globals

\section{Citing this paper}

Please note that where the full-text provided on Manchester Research Explorer is the Author Accepted Manuscript or Proof version this may differ from the final Published version. If citing, it is advised that you check and use the publisher's definitive version.

\section{General rights}

Copyright and moral rights for the publications made accessible in the Research Explorer are retained by the authors and/or other copyright owners and it is a condition of accessing publications that users recognise and abide by the legal requirements associated with these rights.

\section{Takedown policy}

If you believe that this document breaches copyright please refer to the University of Manchester's Takedown Procedures [http://man.ac.uk/04Y6Bo] or contact uml.scholarlycommunications@manchester.ac.uk providing relevant details, so we can investigate your claim.

\section{OPEN ACCESS}


Do born global SMEs reap more benefits from ICT use than other internationalizing small firms?

\section{This is a pre-print / an Author's Original Manuscript (AAM) of an article published by Edward Elgar Publishing in the Handbook of Research on Born Globals. Please cite the published chapter:}

Pezderka, Noemi, Rudolf R. Sinkovics, and Ruey-Jer 'Bryan' Jean (2012), "Do born global SMEs reap more benefits from ICT use than other internationalizing small firms?," in Handbook of research on born globals, Mika Gabrielsson and V.H. Manek Kirpalani (Eds.). Cheltenham, UK: Edward Elgar, 185-213. https://doi.org/10.4337/9780857938046.00021

Noemi Sinkovics (Pezderka)

The University of Manchester, Alliance Manchester Business School Booth Street West, Manchester M15 6PB, UK.

Noemi.Sinkovics@gmail.com http://www.research.manchester.ac.uk/portal/Noemi.Sinkovics.html http://orcid.org/0000-0002-5143-6870

Rudolf R. Sinkovics

The University of Manchester, Alliance Manchester Business School

Booth Street West, Manchester M15 6PB, UK.

Rudolf@sinkovics.com http://www.manchester.ac.uk/research/rudolf.sinkovics http://orcid.org/0000-0002-4471-5054

Ruey-Jer 'Bryan' Jean Professor of International Business National Chengchi University

64, Sec.2 Zhi-Nan Road, Taipei, 11605, Taiwan bryan@nccu.edu.tw https://orcid.org/0000-0003-2461-7454 


\begin{abstract}
The existence of rapidly internationalising small to medium sized firms has been widely documented in the literature. Liberalisation of markets and the emergence of new Information and Communication Technologies (ICT) are the most frequently cited enablers of this phenomenon. However, despite their unprecedented potential to reach customers and reduce trade barriers, the anticipated positive impact of ICTs on firm performance has not been empirically supported to the expected degree. This study addresses this topical issue and investigates the effect of online media use on export performance by using multivariate statistical analysis on data drawn from a survey of 115 UK-based SMEs.
\end{abstract}

\title{
Keywords
}

Born-Global; SME; ICT; Internationalization; Performance

\section{Acknowledgements}

We are grateful to Mika Gabrielsson and V.H. Manek Kirpalani for their thoughtful steering of this manuscript towards successful publication. Previous versions of this manuscript were presented at academic conferences, including CIMaR 2010 in Oslo, Norway and the EIBA 2010 conference in Porto, Portugal. We gratefully acknowledge insightful comments received from anonymous conference reviewers and participants in the discussions, specifically Carl Arthur Solberg, Catherine Axinn and Mo Yamin. We also appreciate intellectually stimulating interactions with colleagues from the Comparative and International Business Research Centre (CIBER) at Manchester Business School. 


\title{
Do born-global SMEs reap more benefits from ICT use than other internationalising small firms?
}

\begin{abstract}
The existence of rapidly internationalising small to medium sized firms has been widely documented in the literature. Liberalisation of markets and the emergence of new Information and Communication Technologies (ICT) are the most frequently cited enablers of this phenomenon. However, despite their unprecedented potential to reach customers and reduce trade barriers, the anticipated positive impact of ICTs on firm performance has not been empirically supported to the expected degree. This study addresses this topical issue and investigates the effect of online media use on export performance by using multivariate statistical analysis on data drawn from a survey of 115 UK-based SMEs.
\end{abstract}

KEYWORDS: born-global; SME; ICT; Internationalization; Performance 


\section{Introduction}

The emergence and spread of Information and Communication Technologies (ICT) gave rise to speculations about their potential impact in many walks of life. Interestingly, despite the rapidly growing literature on e-commerce, research on the Internet's impact on firm internationalisation is comparatively limited. In a recent review of 45 empirical studies, MorganThomas et al. (2009) identifies two major streams within the "online internationalisation" literature, a) the internationalisation of e-commerce corporations and b) the impact of the Internet on the internationalisation of non-Internet-based firms. The present study focuses on firms which belong to the latter category.

The beginning of empirical International Business (IB) research on ICT issues dates back to the seminal work of Hamill and Gregory (1997: 9) predicting a "revolutionary impact on the conduct of international trade". Macro-level studies, correlating Internet access with international trade growth (e.g. Freund and Weinhold 2004) seem to confirm this prediction. Furthermore, anecdotal evidence about the export opportunity enhancing nature of the Internet in developing countries (e.g. Wheeler, Dasgupta, and Lall 2004) was supported by empirical results indicating a higher propensity to export among firms with Internet access in Eastern Europe and Central Asia (Clarke 2008). Yet, these results merely indicate that ICT, more precisely the Internet, play an important role in facilitating international trade without conveying a specific link about their contribution to export performance.

As pointed out by Anna Morgan-Thomas (2009), given the Internet's unprecedented potential to reach foreign customers (Schlegelmilch and Sinkovics 1998; Yamin and Sinkovics 2006), and the trend towards increased e-enablement (Morrison, Bouquet, and Beck 2004), it is surprising how limited research is on the direct contribution of ICT to export performance. Finding out when ICTs matter is even more pressing as they are approaching the end of their build-out phase (Carr 2003). This means that these are becoming widely available at affordable prices, erasing the potential for financial benefits by their mere adoption. Today, "[t]he key question is not whether to deploy Internet technology but "how" to deploy it... companies have no choice if they want to stay competitive" (Porter 2001: 64).

Furthermore, not only is the number of empirical studies on this subject matter limited, the results are highly inconsistent calling for more investigation. In addition, while existing studies have - to varying degrees - covered ICT deployment dimensions such as "complementary IT resources" (Morgan-Thomas 2009), "relationship building” (e.g. Morgan-Thomas and 
Bridgewater 2004), “investment into IT" (Morgan-Thomas and Bridgewater 2004), "communication" (Raymond, Bergeron, and Blili 2005), "online transactions" (e.g. Moen, Madsen, and Aspelund 2008), "market intelligence" (e.g. Moon and Jain 2007), "product services" (e.g. Moon and Jain 2007), “cost reduction" (e.g. Lu and Julian 2007), to date there is no empirical study testing the impact of the Internet as an alternative to physical foreign market entry mode on export performance. To this end, this study aims to fill this gap and to contribute to a better understanding of which Internet-deployment practices actually contribute to an enhanced export performance.

The question of "how" to deploy the Internet cannot be separated from the context of deployment. There is empirical evidence, that young and fast growing firms, also termed as "born globals" are highly relying on ICT as a growth facilitator (e.g. Arenius, Sasi, and Gabrielsson 2005; Hodgkinson 2008; Servais, Madsen, and Rasmussen 2007). However, rapid growth cannot be equated with better financial performance. Thus, the present study also aims at investigating whether ICT deployment contributes more to born global firms' export performance than to the export performance of enterprises that follow a slower internationalization pattern.

\section{Literature Review}

\subsection{ICT deployment and export performance}

Following a comprehensive survey of the literature on ICT and export performance using online databases such as ABI/Inform and EBSCO, we identified nine empirical studies measuring the impact of the Internet on export performance (see Table 1). Eight of these studies directly correlated Internet use with performance measures, and one study investigated the mediating impact of Internet-integration into marketing activities on export performance. While two of the studies operationalized Internet use very broadly by measuring it as "Internet sales" and "Internet access" respectively (see Clarke 2008; Hodgkinson 2008), the rest of the papers attempted to capture Internet use by devising multiple categories.

Morgan-Thomas (2009) and Morgan-Thomas and Bridgewater (2004) investigated the impact of 'complementary IT resources' and 'IT capability development' efforts on the online contribution to export performance. The former category encompasses factors such as the sophistication of IT infrastructure and IT staff as well as heavy investments in IT systems and applications. IT capability efforts include high time and resource investments into Internet deployment, a high ongoing Internet budget, and substantial planning of Internet activities. Marketing activities replaced by the Internet were measured by examining company websites. The 
web contents have been classified into four categories, i.e. information content, relationship building features, online transaction features, and sophistication of the website. Prasad et al. (2001), Raymond et al. (2005) as well as Moen et al. (2008) broke down ICT deployment into three main dimensions, i.e. market research, sales/transaction functions, and relationship development. In contrast to Morgan Thomas (2009) and Morgan-Thomas and Bridgewater (2004), these authors used Likert-type scale items to measure the relational dimension. While also accounting for marketing research and online transaction dimensions, Moon and Jain (2007) operationalized ICT deployment by additionally measuring the firm's dependence on the Internet for new product development, advertising, and for providing product service support. Lu and Julian (2007) complemented the list of dimensions by adding "cost reduction", "networking", "image enhancement", and "competitive advantage".

Although there seems to be a convergence in terms the categorisation of ICT deployment (information/relationship building/transactions), the results of the studies are controversial. Seven out of the nine studies directly investigate the relationship between the transaction dimension of Internet use and export performance. Contrary to expectations, only Hodgkinson (2008) found a positive significant relationship. The results indicated that fast growth firms also known as born globals tend to use e-commerce as an early-stage internationalisation mode. However, in that study export performance is solely operationalized as fast/good/modest/negative export growth not accounting for the financial dimension. While Raymond et al. (2005) also found a significant positive relationship between online transactions/collaboration and sales growth, the export sales ratio (export sales/total sales) remained unaffected.

There is only limited evidence for the relationship building potential of ICT (MorganThomas 2009). Resource commitment to Internet deployment in terms of allocated time, budget, and planning activities seem to positively influence export performance (Morgan-Thomas 2009; Morgan-Thomas and Bridgewater 2004). The sophistication of the website, i.e. the existence of multiple pages, regular content updates, different language versions, own domain name, as well as the registration with major search engines also appear to have a positive impact on export success of virtual channels (Morgan-Thomas and Bridgewater 2004).

The use of the Internet for business intelligence purposes yielded controversial results. While Raymond et al. (2005) found that prospecting for clients and developing competitive intelligence through online media can damage the export sales ratio, Moon and Jain (2007) identified a positive relationship between Internet marketing research and export profit. However, it needs to be noted, that in Moon and Jain's (2007) study, Internet marketing research was 
operationalized as the company's dependence on the Internet for carrying out marketing intelligence as well as the quality of the company's capability to carry out marketing research on the Internet. The same operationalization strategy was applied to two further constructs displaying a positive impact on export profits, i.e. promotion and product support.

\section{Insert Table 1 about here}

The above review of existing empirical studies indicates that results on the contribution of ICT deployment to export performance are contradictory. These inconsistencies partially stem from differences in the operationalization of the identified dimensions. A further reason might be attributed to the time frame of data collection. It seems that a large part of the data was gathered prior to 2005. Given the maturation and rapid expansion of the Internet infrastructure, and the incorporation of IT in the education systems, it can be expected that external pressure to engage in e-business is increasing rapidly. Consequently, there is need for further testing.

\subsection{ICT deployment and born global firms}

Although there is some empirical evidence that Internet use positively correlates with firm internationalization, the causality of this relationship could not be sufficiently determined (Clarke 2008). In response to the causality question, the born global stream of the internationalization literature posits that the Internet acts as an internationalization enabler. The underlying assumption is that born global firms are relatively small and limited in terms of their resource endowments (Hodgkinson 2008). Hence, they are suggested to deploy the Internet in order to proactively counterbalance these initial limitations (Kotha, Rindova, and Rothaermel 2001; Servais, Madsen, and Rasmussen 2007). Given the importance of technology leadership, including the reliance on ICT for the success of born globals (Knight and Cavusgil 2005), the number of empirical studies investigating their ICT deployment strategies is surprisingly limited (Gabrielsson and Gabrielsson).

While Arenius et al. (2005) and Gabrielsson and Gabrielsson (2010) mainly focused on the qualities of the Internet as a sales channel, Moen et al. (2003) and Loane (2005) identified a wide range of ICT use dimensions ranging from e-mail communication to competitor analysis. Servais et al. (2007) went beyond a simple deployment analysis and investigated the difference between born global and non-born global firms in terms of Internet use. Their results show that born global firms rely on the Internet more intensively than their non-born global counterparts. Other studies 
examined the facilitating effect of the Internet on firm internationalization (e.g. Hodgkinson 2008; Kotha, Rindova, and Rothaermel 2001; Loane, McNaughton, and Bell 2004), however, to our best knowledge there are no studies investigating the impact of Internet use on born-global performance.

In this study we define born globals as firms that internationalize within three years of their inception, have an export ratio of at least $25 \%$, and operate in three or more different continents (Sundqvist, Kuivalainen, and Cadogan 2010).

\section{Conceptual framework and hypotheses}

The inconsistency in existing empirical results on the relationship between internet deployment practices and export performance (as pointed out in section 2.1) may be due to the way these dimensions have been operationalized. By that we primarily mean the underlying theoretical assumptions. Although no theory has been explicitly indicated, those dimensions which have been found to have a significant positive or negative impact on export performance were implicitly or explicitly connected to capability development (Moon and Jain 2007; MorganThomas 2009; Morgan-Thomas and Bridgewater 2004) or to the expectation that the Internet represents a resource-advantage ( $\mathrm{Lu}$ and Julian 2007).

Based on these empirical results, among the currently existing theories in international business, the resource-based view would seem to be the one with the greatest explanatory value. However, as pointed out by $\mathrm{Wu}$ et al. (2006), Internet use alone does not satisfy the criteria demanded by RBV (Barney 1991). Reliance on the Internet and other ICT is more of a strategic necessity than a source of sustainable competitive advantage. (Clemons and Row 1991; Powell and Dent-Micallef 1997). Powell and Dent-Micallef (1997) established that IT resources need to be embedded into an organization in order to contribute to value creation. Their results showed that "ITs can produce competitive advantage by leveraging or exploiting Human and Business resources" (Powell and Dent-Micallef 1997: 392). Also building on RBV, Wu et al. (2006: 494) proposed and found empirical evidence that when IT technology is embedded in a firm's supply chain processes, IT can contribute to the development of "higher-order organizational capabilities [...] which are firm specific and hard to duplicate across organizations". Similarly, Prasad et al. (2001) found evidence that the integration of Internet technology into marketing activities enhance marketing capabilities, and through these enhanced capabilities it contributes to export performance.

In contrast to $\mathrm{Wu}$ et al. (2006) and Prasad et al. (2001), in this study, we are more 
concerned with Internet-based first-order capabilities. While, as repeatedly suggested empirically, ICT integration into business activities has the potential to enhance the development or effectiveness of higher order capabilities (e.g. Powell and Dent-Micallef 1997), they may also be influenced by a number of other factors not accounted for. In order to better understand the effect of Internet-integration on financial performance, it is important to investigate the relevance of first-order Internet-facilitated capabilities. Consequently, we propose that those firms that develop superior capabilities in terms of communication with customers, relationship-building, reaching potential customers, bypassing costly physical presence in foreign markets, market research, being a front-runner in employing advanced export management technology, and cost reduction through Internet deployment will experience enhanced export performance.

Morgan-Thomas and Bridgewater (2004) found evidence that a high ongoing Internet budget, substantial planning for Internet activities, as well as high investment in terms of time and resources lead to enhanced export performance. In a later publication, using the same data set, Morgan-Thomas (2009) renamed the construct "web investment" into "capability development effort". This is in line with Porter's (2001) argument that IT investment needs to be aligned with a strategy. We take this argument a step further and propose that those firms that develop the capability to identify the most advanced technology available and integrate it into their export management process will witness higher export performance.

\section{H1: The integration of advanced IT technology into a firm's export management processes contribute to enhanced export performance}

Although responsiveness in a world of zero-tolerance is a necessary condition to firm survival (Reeves 2000), there is no empirical evidence that using the Internet for communication purposes has a direct significant impact on export performance by its own merit. However, if through relying on Internet communication a firm achieves a competitive advantage (Lu and Julian 2007), financial benefits can be expected.

\section{H2: A firm's Internet-based communication capabilities contribute to enhanced export performance.}

Insert Figure 1 about here

Relationship building/maintaining capabilities have been shown to positively impact on firms' export performance. While Morgan-Thomas (2009) focused on website features such as order tracking, online customer service, visitor recognition, etc., Raymond et al. (2005) 
emphasized the collaboration function of Internet technology. Moon and Jain (2007) found a positive relationship between online product service and enhanced profits. We propose that in addition to these dimensions, when a firm uses the Internet as an alternative to physical market entry, it needs to be able to achieve at least the same level of customer satisfaction that it would have achieved by offline market entry.

\section{H3: A firm's Internet-based relationship building capabilities contribute to enhanced export performance.}

There seems to be an agreement in the literature regarding the Internet's unprecedented potential to reach customers (Schlegelmilch and Sinkovics 1998; Yamin and Sinkovics 2006). Using the Internet to generate sales leads (Bennett 1997), or setting up a website to serve as a virtual shopping window (Loane 2005) are examples for numerous possibilities. We propose that firms that identify ways to use the Internet to reach more potential foreign customers will experience better export performance.

\section{H4: A firm's capability to reach foreign customers contributes to enhanced export performance.}

While there is empirical evidence that firms do carry out market research online (Bennett 1997; Loane 2005), when looking at the impact of these activities on export performance, the results are controversial. Prasad et al. (2001) found that online marketing research positively influences the development of marketing capabilities, Raymond et al. (2005) found a negative relationship between e-business intelligence and export performance measured in terms of export sales ratio. Moon and Jain's results (2007), on the other hand, show that Internet marketing research positively impacts profits, sales, as well as firms' market share. This inconsistency calls for further testing. Thus we hypothesize that:

\section{H5: Internet-based market research capabilities positively impact firms' export performance.}

Using the Internet as a direct sales channel can be used as an alternative or complement to physical market entry (e.g. Gabrielsson and Gabrielsson 2010). Although there is empirical evidence that using the Internet for online transactions does not have a significant direct impact on firms' export performance (e.g. Moen, Madsen, and Aspelund 2008), there are no studies investigating the impact of the Internet as an alternative market entry mechanism on export performance. Gabrielsson and Gabrielsson (2010) found that Internet-based multiple channels can reduce the liability of foreignness and newness. Nevertheless, earlier research points to firms' conviction that the Internet is an appropriate way to counterbalance the lack of export experience 
(Bennett 1997). This is in line with Morgan-Thomas and Bridgewater's (2004) suggestion that the lack of extensive exporting experience in SMEs may lead to a higher level of commitment to online internationalization. Comparable to the effects of the psychic distance paradox $\left(\mathrm{O}^{\prime}\right.$ Grady and Lane 1996), firms that are aware of their lack of export experience will attempt to compensate through the development of online capabilities.

\section{H6: Internet-based capabilities that allow firms to avoid or reduce physical presence in} a foreign market will experience enhanced export performance.

Despite the expectation that the Internet can help reducing the cost of various business activities (e.g. Bennett 1997), Lu and Julian (2007) did not find a significant positive relationship between the cost reducing use of the Internet and export performance. As to our best knowledge there are no other studies testing this relationship, we deem the inclusion of this dimension in our study appropriate.

\section{H7: Internet-based cost reduction capabilities contribute to enhanced export performance.}

As pointed out in Section 2.2, existing empirical results seem to indicate a difference in Internet reliance between born globals and non-born globals (Servais, Madsen, and Rasmussen 2007). Also industry sector, export experience (Vahlne and Johanson 2002) and Internet technology experience (Berry and Brock 2004) may have a potential impact on the success of firms' performance. Consequently, these factors need to be controlled for.

\section{Method}

\subsection{Measures}

As a first step, we conducted semi-structured telephone interviews with managing directors of five UK-based firms involved in active online internationalization (Yamin and Sinkovics 2006). The website of the selected companies (1) displayed information that indicated an attempt to actively target foreign markets e.g. pricing in various currencies, website translations, cultural specific information, and (2) was transactional rather than purely informative in nature.

These interviews have been used for scale development where no suitable measurement items were found in existing studies (see Table 2). We used seven-point Likert-type multiple-item scales to operationalize all constructs and variables. 


\section{Insert Table 2 about here}

\subsection{Sampling frame and data collection}

The target population was defined as UK based SMEs involved in exporting activities disposing of a website. SMEs were determined using the definition of the European Commission, "the category of micro, small and medium-sized enterprises (SMEs) is made up of enterprises which employ fewer than 250 persons and which have an annual turnover not exceeding EUR 50 million, and/or an annual balance sheet total not exceeding EUR 43 million"(European Commission 2003). In the first step, the criteria were entered into the FAME (Bureau van Dijk) database. It provides detailed, financial, descriptive and ownership information on over 3.1 million public and private companies in the UK and Ireland. In order to determine whether the companies were involved in exporting, we examined whether their profit and loss account contained the position "overseas turnover". The database contained 8,605 companies corresponding to the above mentioned specifications. We drew a random sample of 1,000 companies. The next step involved the website inspection of the selected companies. Those with non-functioning sites or with no explicit exporting activities had to be replaced. As contact person the Marketing, Export or Sales Manager or, in case the formers were not indicated in FAME, the Managing Director was selected.

\subsection{Survey response and informant evaluation}

The first round was in the form of a postal mail out of 1,000 questionnaires. After two weeks only 35 completed questionnaires were received back. In order to increase the response rate, the sample companies were called one by one. By the fifth week after the mail-out, 74 responses were returned. To further improve the response rate, a reminder email was sent out to all managers who agreed on the phone to complete the survey. In total, we received 115 usable questionnaires back, accounting for a response rate of $11.5 \%$.

A random sample of 82 companies was drawn from amongst the non-respondents (who explicitly indicated a non-willingness to respond per post, email or phone) in order to test for nonresponse bias. The majority of non-respondents gave their shortage of time as the major reason for non-response, while merely $6 \%$ indicated being discouraged by the length of the questionnaire (the original questionnaire had 252 scale items). 27\% stated that their company policy would prohibit any participation in surveys. The remaining companies revealed their lack of interest in the topic or other reasons (for example new manager, bankruptcy of the company etc.) for their 
reluctance to reply. However, none of the declines were due to the substance of the questionnaire. Finally, we further assessed non-response bias by comparing selected attribute means of earlyrespondents with those of late-respondents (Armstrong and Overton 1977). The comparison of the means yielded no significant differences.

\subsection{Common method bias}

We assessed common method bias by applying two separate procedures. In a first step, we utilized the Harman one-factor test (Podsakoff and Organ 1986) by performing a principal component analysis of all the items included in the study. Since no dominant factor emerged, we conclude that there is no evidence suggesting the presence of common method bias in the study.

A more advanced step in examining comment method bias involved correlating objective data with subjective data on the same variable. The survey included a question where respondents were asked to indicate their export ratio. We subsequently downloaded the information about the selected firms' export ratio from the FAME database. The test yielded a significant and positive correlation coefficient of 0.675 , again providing support for the assumption that no common method bias was limiting generalizations from our findings.

\section{Assessment of the research model and hypotheses}

\subsection{Measurement model assessment}

First, we examined the loadings of the individual items with their respective constructs (see Table 2). All measurement items with loadings above 0.4 were retained (Ainuddin et al. 2007). The loadings for all measures range from 0.446 to 0.954 , with most items exceeding the threshold level of 0.7 recommended by Fornell and Larcker (1981). In a second step, we examined both the Cronbach's Alpha and the Composite Reliability values for each latent variable. Both measures suggest reasonable reliability with all values exceeding the 0.7 threshold (Nunnally and Bernstein 1994).

Convergent validity was assessed by using the average variance extracted (AVE) (see Table 5) as suggested by Fornell and Larcker (1981). Convergent validity was found satisfactory as all the values are greater than 0.5 (Henseler, Ringle, and Sinkovics 2009). We checked discriminant validity by using two methods, i.e. the Fornell-Larcker criterion (1981) and the cross loadings of items. As for each variable, the AVE is higher than its highest squared correlation with any other variable we can assume an adequate level of discriminant validity. This is supported by the crossloadings. The loading of each indicator is greater than all of its cross-loadings (Henseler, 
Ringle, and Sinkovics 2009).

\section{Insert Table 5 about here}

\subsection{Structural model assessment}

After ensuring that the outer model is both reliable and valid, we examined the inner path model using SmartPLS (Ringle, Wende, and Will 2005). The explanatory power of a PLS model is determined by the extent of variance explained $\left(R^{2}\right)$ by the endogenous latent variables (Henseler, Ringle, and Sinkovics 2009). The $\mathrm{R}^{2}$ value for export performance is 0.345 . Chin (1998) sets the thresholds at $0.67,0.33$, and 0.19 for substantial, moderate, and weak inner path models respectively. Henseler et al. (2009) state that if an endogenous latent variable is explained by only one or two exogenous latent variables, already a "moderate" $\mathrm{R}^{2}$ value is acceptable. Although our coefficients for determination is medium, as the prediction capability of the model is sufficiently high $(\mathrm{cv}$ redundancy $=0.149 ; \mathrm{cv}$ communality $=0.755)$ our results can be deemed as relevant and indicatory for future research. To check the prediction capability of the model, we used StoneGeisser's $Q^{2}$ suggested in Henseler et al. (2009) applying the blindfolding method (Tenenhaus et al. 2005)

\subsection{Results and discussion}

Table 3 and Table 4 display the characteristics of the respondent firms. $50.43 \%$ of the respondents can be categorized as true born globals. These firms have internationalized within three years from their establishment and are exporting more than $25 \%$ of their total sales to at least three continents. In terms of industry affiliation $53.04 \%$ of the cases belong to the high-tech sector (e.g. software, engineering, and computing) and $46.96 \%$ to the low-tech sector (e.g. food and beverages and clothing).

Insert Table 3 about here

Insert Table 4 about here

After performing a chi-square test of independence we conclude that there is no significant 
association between industry affiliation and born-globalness. Moreover, an independent sample ttest does not show differences between born-globals and non-born-globals in terms of their Internet experience measured in years of Internet use. This indicates that the comparison between born-global and non-born global firms will not be affected by the firms' Internet experience or Industry-affiliation.

The average firm age indicates that although born-globals in our sample are still "younger" than non-born globals with an average of 29 and 31 years in the low-tech and high-tech industry respectively, they are past their start-up phase. In order to test whether this fact hampers inferences from the comparison between born globals and non-born globals, we again conducted an independent sample t-test which indicated that the mean difference in firm age was significant. From this we take that even though some of the born global firms have already developed into more mature organizations, we are still able to find relevant differences in terms of the impact of Internet-based capabilities on export performance between born globals and non-born globals.

Our overall results suggest that while certain Internet-based capabilities have indeed the potential to significantly enhance firms' export performance, other Internet deployment dimensions can have a negative effect. Although previous empirical findings indicated such potential damaging impact (e.g. Powell and Dent-Micallef 1997), those results were not significant.

Insert Figure 2 about here 
Figure 2 shows the results of our analysis carried out on the full sample of 115 SMEs. From our hypotheses only $\mathrm{H} 1$ and $\mathrm{H} 4$ could be fully supported. H1 stated that those firms that succeed at developing capabilities to integrate the most advanced IT technology available their industries into their export management processes will experience enhanced export performance. In line with the literature, $\mathrm{H} 4$ proposed that the Internet has an unprecedented potential to reach potential customers worldwide, and those firms that develop the know-how and skills to harness that potential will benefit through higher financial returns. Our findings allow us to go beyond previous inferences based on empirical evidence that ICT integration only facilitates higher-order capability development (e.g. Powell and Dent-Micallef 1997; Wu et al. 2006). The results seem to confirm that the new technologies can also play an important role in the development of firstorder capabilities. However, as can be seen in the case of $\mathrm{H} 2$ and H6, the use of ICT for active online internationalization bears its own set of risks (Pezderka and Sinkovics 2011). H2 suggested that Internet-based capabilities which allow a firm to overcome language barriers, harvest consumer feedback (Sinkovics, Penz, and Molina Castillo 2009), and to enhance interaction with foreign customers will have an improved performance. However, contrary to our expectations, the results reveal a significant negative relationship between Internet-based communication capabilities and export performance. The analysis of $\mathrm{H} 6$ proposing a positive relationship between the use of the Internet as an alternative to physical presence in foreign countries and firm performance yielded similarly negative results. One possible explanation for these disadvantageous effects may be Yamin and Sinkovics's "virtuality trap". This is in essence the managerial perception that the exploration of "underlying market conditions" can be sufficiently carried out by the sole reliance on ICT (Yamin and Sinkovics 2006: 349). H3, H5 and H7 were not supported.

In a subsequent step, we controlled for firms' born globalness, industry affiliation, degree of export experience, as well as Internet experience by adopting Jaccard and Turrisi's approach (2003). We measured industry affiliation by dividing our sample of 115 companies into two categories, i.e. low-tech and high-tech respectively. Export experience was operationalized using firms' indicated export ratio. We used the number of years a firm has been using the Internet as a proxy for Internet experience. Table 6 summarizes the results.

Whereas industry affiliation and Internet experience do not seem to have any significant impact on our main findings, the analysis revealed that born globalness and export experience require closer attention. 


\section{Insert Table 6 about here}

While none of the ICT deployment dimensions had a significant contribution to non-global firms' performance, in the case of born globals Internet-based communication capabilities indicated a negative significant effect.

An even more interesting finding emerged when we controlled for how the degree of export experience influences export performance. In line with our main findings before splitting the sample, firms with less export experience $(<50 \%$ export ratio) seem to suffer financial losses when relying on the Internet as an alternative to physical market entry. Surprisingly, their export performance was also affected when they integrated advanced information technologies into their export management processes. Companies with more export experience ( $>50 \%$ export ratio), on the other hand, displayed enhanced export performance for the same Internet deployment dimensions.

A possible explanation for the controversial impact of IT integration may be that investment in advanced IT systems for export management needs to be aligned with the company's export intensity. In this case, the advancement of IT systems can be regarded as a proxy to the amount invested in that system. However, if firms invest more than their return on investment on that particular information technology, this will lead to losses at the profit level.

The second finding may be attributed to two issues. Firstly, as mentioned earlier, online internationalization has its own array of risks. Despite the expectation that virtual market entry eliminates traditional international risks, most of these risks reemerge in a transformed manner (Pezderka and Sinkovics 2011). Secondly, the importance of relationships in the target country (Gabrielsson and Gabrielsson 2010) can be easily underestimated due to the virtuality trap (Yamin and Sinkovics 2006). Firms with increased export experience can be expected to have developed the capabilities to manage international e-risks as well as to have found ways to counterbalance the negative effects of the virtuality trap.

\section{Conclusion and Limitations}

In the 1990s numerous papers concluded that SMEs were not deploying the Internet to their potential (e.g. Hamill and Gregory 1997). After the turn of the century, research attention gradually turned to the pitfalls of overreliance on ICT such as the virtuality trap (Yamin and Sinkovics 2006), overinvestment (Carr 2003), and the lack of a clear deployment strategy (Porter 
2001). The present paper set out to investigate in how far deploying the Internet contributed to small internationalizing firms' export performance. Our findings support the relevance of these new emerging concerns. Although born globals seem to be more susceptible to fall into the communication dimension of the virtuality trap than other types of firms, a positive or negative contribution to export performance appears to be mostly influenced by a firm's export experience. Our results suggest that firms with more export experience ( $>50 \%$ export ratio) have already developed the capabilities to transcend the virtuality trap, and thus experience enhanced export performance. On the other hand, firms with less export experience $(<50 \%$ export ratio), seem to overestimate the importance of IT investments and neglect the relevance of their offline/physical market experience. In summary, based on the outcome of our analysis we conclude that the Internet can be best compared to a double edge sword. It has indeed the potential to enhance the development of first-order capabilities that can contribute to enhanced export performance. Yet, when its use is not aligned with strategy (Porter 2001) it can lead to financial damage.

The main limitation of this study is the small sample size. Although PLS is a powerful tool in dealing with small samples (Graham, Mintu, and Rodgers 1994), a larger sample would allow for more variations in terms of splitting the data. A further limitation is that some of the firms that qualified as born globals are already past their start-up phase. Although, we can still draw inferences from the results, future research may look into testing our findings with a subset of born-globals in their infancy. Future research may also consider further investigating the circumstances under which ICT deployment directly contributes to firm performance.

\section{References}

Ainuddin, R. Azimah, Paul W. Beamish, John S. Hulland, and Michael J. Rouse (2007), "Resource Attributes and Firm Performance in International Joint Ventures," Journal of World Business, 42 (1), 47-60.

Arenius, Pia, Viveca Sasi, and Mika Gabrielsson (2005), "Rapid Internationalisation Enabled by the Internet: The Case of a Knowledge Intensive Company," Journal of International Entrepreneurship, 3 (4), 279-290.

Armstrong, J. Scott and Terry S. Overton (1977), "Estimating Nonresponse Bias in Mail Surveys," Journal of Marketing Research, 14 (3), 396-402.

Barney, Jay B. (1991), "Firm Resources and Sustained Competitive Advantage," Journal of Management, 17 (1), 99-121.

Bennett, Roger (1997), "Export Marketing and the Internet: Experiences of Web Site Use and Perceptions of Export Barriers among UK Businesses," International Marketing Review, 14 (5), 324-344.

Berry, Maureen M. J. and Jürgen Kai-Uwe Brock (2004), "Marketspace and the Internationalisation Process of the Small Firm," Journal of International Entrepreneurship, 2 (3), 187-216.

Carr, Nicholas G. (2003), "It Doesn't Matter," Harvard Business Review, 81 (5), 41-49. 
Chin, Wynne W. (1998), "The Partial Least Squares Approach to Structural Equation Modelling," in Modern Methods for Business Research, George A. Marcoulides (Ed.). Mahwah, NJ: Lawrence Erlbaum Associates, 295-358.

Clarke, George R. G. (2008), "Has the Internet Increased Exports for Firms from Low and Middle-Income Countries," Information Economics and Policy, 20 (1), 16-37.

Clemons, Eric K. and Michael C. Row (1991), "Sustaining IT advantage: The Role of Structural Differences," MIS Quarterly, 15 (3), 275-292.

Eriksson, Kent, Jan Johanson, Anders Majkgård, and D. Deo Sharma (1997), "Experiential Knowledge and Cost in the Internationalization Process," Journal of International Business Studies, 28 (2), 337360.

European Commission (2003, June 20), Commission Recommendation of 6 May 2003 Concerning the Definition of Micro, Small and Medium-Sized Enterprises (L 124/36 ed.), [Online]. Available: http://europa.eu/eur-lex/pri/en/oj/dat/2003/1 124/1 12420030520en00360041.pdf [2008, June 20].

Forbes, Chloe (2006), "Online Internationalisation \& Psychic Distance - Questionnaire Development, Measurement Item Generation \& Preliminary Tests," MSc dissertation, Manchester, UK: The University of Manchester.

Fornell, Claes and David F. Larcker (1981), "Structural Equation Models with Unobservable Variables and Measurement Error: Algebra and Statistics," Journal of Marketing Research, 18 (3), 382-388.

Freund, Caroline L. and Diana Weinhold (2004), "The Effect of the Internet on International Trade," Journal of International Economics, 62 (1), 171-189.

Gabrielsson, Mika and Peter Gabrielsson (2010), "Internet-Based Sales Channel Strategies of Born Global Firms," International Business Review, In Press, doi: 10.1016/j.ibusrev.2010.05.001.

Graham, John L., Alma T. Mintu, and Waymond Rodgers (1994), "Explorations of Negotiation Behaviors in Ten Foreign Cultures Using a Model Developed in the United States," Management Science, 40 (1), 72-95.

Hamill, Jim and Karl Gregory (1997), "Internet Marketing in the Internationalisation of UK SMEs," Journal of Marketing Management, 13 (1-3), 9-28.

Henseler, Jörg, Christian M. Ringle, and Rudolf R. Sinkovics (2009), "The Use of Partial Least Squares Path Modeling in International Marketing," Advances in International Marketing, 20, 277-319.

Hodgkinson, Ann (2008), "What Drives Regional Export Performance? Comparing the Relative Significance of Market Determined and Internal Resource Factors," Australasian Journal of Regional Studies, 14 (1), 27-46.

Jaccard, James and Robert Turrisi (2003), Interaction Effects in Multiple Regression (Quantitative Applications in the Social Sciences). Thousand Oaks, California: Sage Publications.

Katsikeas, Constantine S., Leonidas C. Leonidou, and Neil A. Morgan (2000), "Firm-Level Export Performance Assessment: Review, Evaluation, and Development," Journal of the Academy of Marketing Science, 28 (4), 493-511.

Knight, Gary A. and Tamer S. Cavusgil (2005), "A Taxonomy of Born-Global Firms," Management International Review, 45 (3), 15-35.

Kotha, Suresh, Violina P. Rindova, and Frank T. Rothaermel (2001), "Assets and Actions: Firm-Specific Factors in the Internationalization of U.S. Internet Firms," Journal of International Business Studies, 32 (4), 769-791.

Loane, Sharon (2005), "The Role of the Internet in the Internationalisation of Small and Medium Sized Companies," Journal of International Entrepreneurship, 3 (4), 263-277.

Loane, Sharon, Rod B McNaughton, and Jim Bell (2004), "The Internationalization of Internet-Enabled Entrepreneurial Firms: Evidence from Europe and North America," Canadian Journal of Administrative Sciences, 21 (1), 79-97.

Lu, Vinh Nhat and Craig C. Julian (2007), "The Internet and Export Marketing Performance," Asia Pacific Journal of Marketing and Logistics, 19 (2), 127-144.

Moen, Øystein, Iver Endresen, and Morten Gavlen (2003), "Use of the Internet in International Marketing: A Case Study of Small Computer Software Firms," Journal of International Marketing, 11 (4), 129-149.

Moen, Øystein, Tage Koed Madsen, and Arild Aspelund (2008), "The Importance of the Internet in International Business-to-Business Markets," International Marketing Review, 25 (5), 487-503. 
Moon, Byeong-Joon and Subhash C. Jain (2007), "Determinants and Outcomes of Internet Marketing Activities of Exporting Firms," Journal of Global Marketing, 20 (4), 55-71.

Morgan-Thomas, Anna (2009), "Online Activities and Export Performance of the Smaller Firm: A Capability Perspective," European Journal of International Management, 3 (3), 266-285

Morgan-Thomas, Anna and Susan Bridgewater (2004), "Internet and Exporting: Determinants of Success in Virtual Export Channels," International Marketing Review, 21 (4), 393-408.

Morrison, Allen, Cyril Bouquet, and John Beck (2004), "Netchising: The Next Global Wave?," Long Range Planning, 37 (1), 11-27.

Nunnally, Jum C. and Ira H. Bernstein (1994), Psychometric Theory (3rd ed.). New York: McGraw-Hill. O' Grady, Shawna and Henry W. Lane (1996), "The Psychic Distance Paradox," Journal of International Business Studies, 27 (2), 309-333.

Pezderka, Noemi and Rudolf R. Sinkovics (2011), "A Conceptualization of E-Risk Perceptions and Implications for Small Firm Active Online Internationalization," International Business Review, 20 (4), 409-422.

Podsakoff, Philip M. and Dennis W. Organ (1986), "Self-Reports in Organizational Research: Problems and Prospects," Journal of Management, 12 (4), 531-544.

Porter, Michael E. (2001), "Strategy and the Internet.," Harvard Business Review, 79 (3), 62-78.

Powell, Thomas C. and Anne Dent-Micallef (1997), "Information Technology as Competitive Advantage: The Role of Human, Business, and Technology Resources," Strategic Management Journal, 18 (5), 375-405.

Prasad, V Kanti, K Ramamurthy, and G M. Naidu (2001), "The Influence of Internet-Marketing Integration on Marketing Competencies and Export Performance," Journal of International Marketing, 9 (4), 82-110.

Raymond, Louis, Francois Bergeron, and Sam Blili (2005), "The Assimilation of E-Business in Manufacturing SMEs: Determinants and Effects on Growth and Internationalization," Electronic Markets, 15 (2), 106-118.

Reeves, Joanna Ed. (2000), Business Risk. London: Caspian Publishing Ltd.

Ringle, Christian Marc, Sven Wende, and Alexander Will (2005), Smartpls 2.0 M3. Hamburg, Germany: University of Hamburg.

Schlegelmilch, Bodo B. and Rudolf R. Sinkovics (1998), "Marketing in the Information Age - Can We Plan for an Unpredictable Future?," International Marketing Review, 15 (3), 162-170.

Servais, Per, Tage Koed Madsen, and Erik S. Rasmussen (2007), "Small Manufacturing Firms' Involvement in International E-Business Activities," Advances in International Marketing, 17, 297-317.

Sinkovics, Rudolf, Elfriede Penz, and Francisco Jose Molina Castillo (2009), "Qualitative Analyse von Online Communities Für Neuproduktentscheidungen," der Markt, 48 (1), 61-72.

Sundqvist, Sanna, Olli Kuivalainen, and John W. Cadogan (2010, April 8-10), "Contingency Factors in Entrepreneurial Orientation-Perfromance Relationship of Firms with Different Levels of Internationalization." in Colm Kearney (Ed.), 37th Annual Conference Academy of International Business, UK \& Ireland Chapter, Dublin, Ireland, CD-Rom.

Tenenhaus, Michel, Vincenzo Esposito Vinzi, Yves-Marie Chatelin, and Carlo Lauro (2005), "Pls Path Modeling," Computational Statistics \& Data Analysis, 48 (1), 159-205.

Vahlne, Jan-Erik and Jan Johanson (2002), "New Technology, New Companies, New Business Environments and New Internationalisation Processes?," in Critical Perspectives on Internationalisation, Virpi Havila, Mats Forsgren, and Håkan Håkansson (Eds.). Amsterdam, NL: Pergamon, 209-227.

Wheeler, David, Susmita Dasgupta, and Somik Lall (2004), "Policy Reform, Economic Growth, and the Digital Divide:An Econometric Analysis," in World Bank Policy Research Working Paper No. 2567. Washington, DC.

Wu, Fang, Sengun Yeniyurt, Daekwan Kim, and S. Tamer Cavusgil (2006), "The Impact of Information Technology on Supply Chain Capabilities and Firm Performance: A Resource-Based View," Industrial Marketing Management, 35 (4), 493-504.

Yamin, Mohammad and Rudolf R. Sinkovics (2006), "Online Internationalisation, Psychic Distance Reduction and the Virtuality Trap," International Business Review, 15 (4), 339-360. 


\section{Appendix - Tables and Figures}

Table 1: Empirical studies investigating the relationship between ICT use and export performance

\begin{tabular}{|c|c|c|c|c|}
\hline $\begin{array}{l}\text { Author/Location of } \\
\text { sample firms }\end{array}$ & Main research objective & $\begin{array}{l}\text { ICT deployment } \\
\text { operationalized as }\end{array}$ & $\begin{array}{l}\text { Export performance operationalized } \\
\text { as }\end{array}$ & Findings \\
\hline $\begin{array}{l}\text { Hodgkinson (2008) } \\
\text { Australia }\end{array}$ & $\begin{array}{l}\text { Determining the relationship } \\
\text { between export growth } \\
\text { performance and a series of } \\
\text { market orientated and } \\
\text { internal resource variables }\end{array}$ & Internet sales & $\begin{array}{l}\text { Export growth } \\
\text { (fast/good/modest/negative) }\end{array}$ & $\begin{array}{l}\text { Fast growth firms that are relatively small in } \\
\text { size and have limited business and export } \\
\text { experience are more likely to use Internet sales } \\
\text { as an early stage entry mode }\end{array}$ \\
\hline $\begin{array}{l}\text { Clarke (2008) } \\
\text { Eastern Europe and } \\
\text { Central Asia }\end{array}$ & $\begin{array}{l}\text { Does Internet access affect } \\
\text { export performance? }\end{array}$ & Internet access & $\begin{array}{l}\text { Enterprise exports } \\
\text { Exports as percent of sales for } \\
\text { enterprises that export }\end{array}$ & $\begin{array}{l}\text { Firms with Internet access are more likely to } \\
\text { export, however they do not export more than } \\
\text { non-Internet user exporters }\end{array}$ \\
\hline $\begin{array}{l}\text { Morgan-Thomas } \\
(2009) \\
\text { UK }\end{array}$ & $\begin{array}{l}\text { Investigation of antecedents } \\
\text { to online contribution to } \\
\text { export performance (OCEP) }\end{array}$ & $\begin{array}{l}\text { Complementary IT resources } \\
\text { (advancement of IT, IT } \\
\text { expertise of staff, investment } \\
\text { in IT technology) } \\
\text { Online capabilities } \\
\text { (relationship/transaction } \\
\text { elements of website) } \\
\text { Capability development } \\
\text { effort (resource allocation to } \\
\text { Internet deployment) }\end{array}$ & $\begin{array}{l}\text { Perceived contribution of Internet to } \\
\text { - } \quad \text { Export profits } \\
\text { - } \quad \text { \# of foreign markets served } \\
\text { - } \quad \text { Export sales } \\
\text { - } \quad \text { Overall performance }\end{array}$ & $\begin{array}{l}\text { Capability development effort (beta }=0.19 ; \\
\text { relational capability }(0.08) \text { have positive } \\
\text { significant impact on OCEP } \\
\text { Complementary IT resources and transaction } \\
\text { capability have no significant impact on OCEP } \\
\text { Length of export experience has a negative } \\
\text { significant impact on OCEP } \\
\text { Own export department and export intensity } \\
\text { have a positive significant impact on OCEP }\end{array}$ \\
\hline $\begin{array}{l}\text { Morgan-Thomas } \\
\text { and Bridgewater } \\
(2004) \\
\text { UK }\end{array}$ & $\begin{array}{l}\text { Identification of the factors } \\
\text { that influence success in } \\
\text { using virtual channels to } \\
\text { export markets }\end{array}$ & $\begin{array}{l}\text { Investment in virtual } \\
\text { channels } \\
\text { Sophistication of the } \\
\text { technology used } \\
\text { Technological experience } \\
\text { Transaction capability } \\
\text { Relationship capability }\end{array}$ & $\begin{array}{l}\text { Perceived impact of virtual export } \\
\text { channels on export sales, export } \\
\text { profit, number of markets served and } \\
\text { overall performance }\end{array}$ & $\begin{array}{l}\text { Investment and Sophistication have a positive } \\
\text { impact on virtual export channel success }\end{array}$ \\
\hline $\begin{array}{l}\text { Prasad, } \\
\text { Ramamurthy and } \\
\text { Naidu (2001) } \\
\text { USA }\end{array}$ & $\begin{array}{l}\text { Investigation of the extent to } \\
\text { which the integration of the } \\
\text { Internet into marketing } \\
\text { activities mediates the } \\
\text { impact of market orientation } \\
\text { on firms' marketing }\end{array}$ & $\begin{array}{l}\text { Customer related marketing } \\
\text { activities } \\
\text { Field sales and channel } \\
\text { member related marketing } \\
\text { activities } \\
\text { Marketing research related }\end{array}$ & $\begin{array}{l}\text { Building awareness and image } \\
\text { overseas } \\
\text { Entering key markets abroad } \\
\text { Sales growth } \\
\text { Gaining new technology/expertise } \\
\text { Improve market share position } \\
\end{array}$ & $\begin{array}{l}\text { Greater integration of the Internet into } \\
\text { marketing strengthens the relationship between } \\
\text { competitor orientation and marketing } \\
\text { competencies, and interfunctional orientation } \\
\text { and marketing competencies of exporting firms } \\
\text { Greater integration of the Internet into }\end{array}$ \\
\hline
\end{tabular}




\begin{tabular}{|c|c|c|c|c|}
\hline & competencies & $\begin{array}{l}\text { and management } \\
\text { communication activities }\end{array}$ & Profitability & $\begin{array}{l}\text { marketing does not strengthen the relationship } \\
\text { between customer orientation and marketing } \\
\text { competencies of exporting firms }\end{array}$ \\
\hline $\begin{array}{l}\text { Raymond, } \\
\text { Bergeron, and Blili } \\
(2005) \\
\text { Canada }\end{array}$ & $\begin{array}{l}\text { Investigation of the extent to } \\
\text { which e-business } \\
\text { assimilation contributes to } \\
\text { the growth and } \\
\text { internationalization of } \\
\text { manufacturing SMEs }\end{array}$ & $\begin{array}{l}\text { Communicational/Informati } \\
\text { onal use } \\
\text { Business intelligence use } \\
\text { Transactional/collaborative } \\
\text { use }\end{array}$ & $\begin{array}{l}\% \text { of sales growth } \\
\% \text { of sales exported }\end{array}$ & $\begin{array}{l}\text { There is a positive significant relationship } \\
\text { between transaction/collaborative use of the } \\
\text { Internet and sales growth. } \\
\text { There is a significant but negative relationship } \\
\text { between the use of e-business intelligence and } \\
\text { export performance. }\end{array}$ \\
\hline $\begin{array}{l}\text { Moon and Jain } \\
\text { (2007) } \\
\text { USA }\end{array}$ & $\begin{array}{l}\text { Investigation of the } \\
\text { determinants and outcomes } \\
\text { of Internet marketing } \\
\text { activities of large and small- } \\
\text { sized exporting firms }\end{array}$ & $\begin{array}{l}\text { Internet marketing research } \\
\text { Internet product } \\
\text { development } \\
\text { Internet promotion } \\
\text { Internet distribution } \\
\text { Internet product services }\end{array}$ & $\begin{array}{l}\text { Profit } \\
\text { Sales } \\
\text { Market share }\end{array}$ & $\begin{array}{l}\text { Internet marketing research, promotion and } \\
\text { product services positively impact profits } \\
\text { Internet marketing research, promotion and } \\
\text { product services positively impact sales } \\
\text { Internet marketing research and promotion } \\
\text { positively impact market share }\end{array}$ \\
\hline $\begin{array}{l}\text { Lu and Julian } \\
\text { (2007) } \\
\text { Australia }\end{array}$ & $\begin{array}{l}\text { Investigation of the link } \\
\text { between the Internet and } \\
\text { export marketing } \\
\text { performance }\end{array}$ & $\begin{array}{l}\text { Communication } \\
\text { Networking } \\
\text { Market research } \\
\text { Increasing sales volume } \\
\text { Image enhancement } \\
\text { Cost reduction } \\
\text { Competitive advantage }\end{array}$ & $\begin{array}{l}\text { Composite scale measure of: } \\
\text { - Economic export performance } \\
\text { - Strategic export performance } \\
\text { - Satisfaction with the performance } \\
\text { of the export market venture }\end{array}$ & $\begin{array}{l}\text { Only achieving a competitive advantage with } \\
\text { the help of the internet has a positive } \\
\text { significant impact on export performance }\end{array}$ \\
\hline $\begin{array}{l}\text { Moen, Madsen and } \\
\text { Aspelund (2008) } \\
\text { Denmark, Norway }\end{array}$ & $\begin{array}{l}\text { Investigation of ICT use on } \\
\text { market performance }\end{array}$ & $\begin{array}{l}\text { Information search } \\
\text { Sales activities } \\
\text { Relationship development }\end{array}$ & $\begin{array}{l}\text { New market knowledge: } \\
\text { - of distribution channels } \\
\text { - } \quad \text { of competitor strategies } \\
\text { - competence development through } \\
\text { - cooperation } \\
\text { Performance in international markets: } \\
\text { - Market share } \\
\text { - Sales growth } \\
\text { - Sales growth vs. competitors } \\
\text { - Profitability } \\
\text { - } \quad \text { Overall performance assessment }\end{array}$ & $\begin{array}{l}\text { No direct impact on performance, however } \\
\text { direct and significant impact on new market } \\
\text { knowledge } \\
\text { Information search and relationship } \\
\text { development positive impact on new market } \\
\text { knowledge } \\
\text { Sales activities negative impact on new market } \\
\text { knowledge }\end{array}$ \\
\hline
\end{tabular}


Table 2: Measurement scales

\begin{tabular}{|c|c|c|c|}
\hline Original version & Adapted version* & Loading & $t$-value \\
\hline \multicolumn{4}{|l|}{ Communication $(\mathrm{CR}=0.7704)$} \\
\hline $\begin{array}{l}\text { Inability to read, speak, and understand the languages of potential foreign } \\
\text { markets (Bennett 1997) }\end{array}$ & $\begin{array}{l}\text { The internet enables us to overcome difficulties in reading, speaking and } \\
\text { understanding the languages of potential foreign export markets }\end{array}$ & 0.687 & 7.555 \\
\hline Creates a good business image (Bennett 1997) & $\begin{array}{l}\text { The internet allows us to effortlessly communicate a good business image to foreign } \\
\text { customers }\end{array}$ & & \\
\hline Generates useful feedback from foreign customers (Bennett 1997) & $\begin{array}{l}\text { The internet has helped us to gain useful feedback about our products from foreign } \\
\text { customers }\end{array}$ & 0.829 & 13.313 \\
\hline Self-developed & Using the internet, we can interact with foreign customers much quicker & 0.561 & 2.968 \\
\hline \multicolumn{4}{|l|}{ Relationship building $(\mathrm{CR}=0.8086)$} \\
\hline Makes it easy for foreign customers to order goods (Bennett 1997) & The internet makes it easier for our foreign customers to order goods & & \\
\hline Creates ongoing relationships with customers (Bennett 1997) & $\begin{array}{l}\text { The internet improves our ability to create relationships with customers in our } \\
\text { target foreign markets }\end{array}$ & 0.882 & 9.782 \\
\hline Self-developed & $\begin{array}{l}\text { The internet facilitates exchange relationships with customers (e.g. feedback, } \\
\text { comments and after-sales services) }\end{array}$ & 0.802 & 5.030 \\
\hline $\begin{array}{l}\text { We support customers online and customers seem happy with that (F1 L20- } \\
\left.21^{* *}\right)\end{array}$ & The internet improves foreign customer satisfaction & 0.698 & 3.923 \\
\hline Self-developed & Our ability to customise products and services is dramatically improved by the internet & & \\
\hline $\begin{array}{l}\text { We support customers online and customers seem happy with that (F1 L20- } \\
\text { 21) }\end{array}$ & $\begin{array}{l}\text { Dealing with customers online makes it easier for us to satisfy them to our } \\
\text { maximum potential }\end{array}$ & 0.446 & 2.773 \\
\hline \multicolumn{4}{|l|}{ Reaching foreign customers $(\mathrm{CR}=0.8491)$} \\
\hline Creates sales leads (Bennett 1997) & The internet improves our ability to generate foreign sales leads & & \\
\hline $\begin{array}{l}\text { It's [the Internet/ our website] a very good shop window, getting our } \\
\text { products in front of a lot more people (F1 L23-24) }\end{array}$ & The internet helps us to reach more potential foreign customers & 0.834 & 2.393 \\
\hline Self-developed & Because of the internet we get unsolicited enquiries from foreign customers & & \\
\hline Gives the firm a competitive edge over rivals (Bennett 1997) & $\begin{array}{l}\text { Using the internet to target foreign markets gives our company a competitive edge } \\
\text { over rivals }\end{array}$ & 0.884 & 2.683 \\
\hline \multicolumn{4}{|l|}{ Alternative to physical presence $(\mathrm{CR}=0.7193)$} \\
\hline $\begin{array}{l}\text { The net has taken some of that [need to go out to the foreign market] away } \\
\text { though, making the world a lot more level than it used to be (F3 L73-75) }\end{array}$ & $\begin{array}{l}\text { Because of the internet, country visits for exporting purposes are less important than } \\
\text { they used to be }\end{array}$ & & \\
\hline Self-developed & $\begin{array}{l}\text { Any future investment we might make, will go towards having an agent in our foreign } \\
\text { markets }\end{array}$ & & \\
\hline
\end{tabular}




\begin{tabular}{|c|c|c|c|}
\hline Need to obtain foreign representation (Bennett 1997) & $\begin{array}{l}\text { The internet helps us to avoid obtaining foreign representation in our export } \\
\text { markets }\end{array}$ & 0.751 & 5.626 \\
\hline $\begin{array}{l}\text { The visits over there help you to see things that you weren't specifically } \\
\text { being told about by customers (F3 L83-84) }\end{array}$ & $\begin{array}{l}\text { Face-to-face contacts have given us a much better understanding of our industry } \\
\text { in our target foreign markets }\end{array}$ & 0.637 & 3.239 \\
\hline $\begin{array}{l}\text { There have been one or two occasions when we have not gained a client } \\
\text { because we don't have a physical presence (F1 L65-67) }\end{array}$ & $\begin{array}{l}\text { Our company would not have gained the customers we have, had it not been for our } \\
\text { physical presence in our foreign market }\end{array}$ & & \\
\hline $\begin{array}{l}\text { We shouldn't ever completely ditch meeting and greeting the odd supplier } \\
\text { or customer from time to time (F3 L96-96) }\end{array}$ & We should never completely stop meeting our foreign customers in person & 0.566 & 3.205 \\
\hline \multicolumn{4}{|l|}{ Market research $(\mathrm{CR}=0.9303)$} \\
\hline Self-developed & Industry changes in our export markets are easily spotted using the internet & 0.686 & 3.166 \\
\hline $\begin{array}{l}\text { It [the internet] has allowed us to find out what our global competitors are } \\
\text { doing (F3 L34) }\end{array}$ & $\begin{array}{l}\text { The internet has improved our ability to find out what our foreign competitors are } \\
\text { doing }\end{array}$ & 0.688 & 2.762 \\
\hline \multirow{3}{*}{$\begin{array}{l}\text { Lack of business knowledge about competitors, clients and markets abroad } \\
\text { (Eriksson et al. 1997) }\end{array}$} & The internet allows us to gather business knowledge about foreign clients & 0.948 & 7.240 \\
\hline & The internet allows us to gather business knowledge about foreign markets & 0.954 & 7.013 \\
\hline & The internet allows us to gather business knowledge about competitors abroad & 0.954 & 7.311 \\
\hline \multicolumn{4}{|l|}{ Cost reduction $(\mathrm{CR}=0.9806)$} \\
\hline Self-developed & The internet is an inexpensive way of communicating with customers & 0.991 & 9.544 \\
\hline Lowers the cost of international marketing (Bennett 1997) & $\begin{array}{l}\text { Using the internet to market our products and services internationally lowers our } \\
\text { overall marketing cost }\end{array}$ & 0.991 & 5.320 \\
\hline Lack of management time to devote to export matters (Bennett 1997) & $\begin{array}{l}\text { The internet helps us overcome problems associated with lack of management time } \\
\text { to devote to export matters }\end{array}$ & 0.791 & 2.412 \\
\hline $\begin{array}{l}\text { Financial costs of exporting additional to those for domestic sales (Bennett } \\
\text { 1997) }\end{array}$ & The internet helps us to reduce the financial costs associated with exporting & 0.990 & 4.449 \\
\hline $\begin{array}{l}\text { Any future resources we might have will go towards that [our online } \\
\text { business] rather than anywhere else (F3 L108-109) }\end{array}$ & In the future we will devote more resources to our online business & 0.991 & 2.859 \\
\hline \multicolumn{4}{|l|}{ Advanced export management technology $(\mathrm{CR}=0.9113)$} \\
\hline $\begin{array}{l}\text { My business unit uses the most advanced IT for supply chain } \\
\text { communication system (Wu et al. 2006) }\end{array}$ & $\begin{array}{l}\text { Our company uses the most advanced IT systems to interact with our foreign } \\
\text { customers }\end{array}$ & 0.860 & 9.494 \\
\hline Relative to our competitors, our supply chain con & Relative to our competitors, our IT for export management is more advanced & 0.864 & 8.612 \\
\hline
\end{tabular}




\begin{tabular}{|c|c|c|c|}
\hline \multicolumn{4}{|l|}{ more advanced (Wu et al. 2006) } \\
\hline $\begin{array}{l}\text { My business unit is always first to use new IT for supply chain } \\
\text { communication system in our industry (Wu et al. 2006) }\end{array}$ & $\begin{array}{l}\text { In our industry, our company is always first to use new IT for management of our } \\
\text { international operations }\end{array}$ & 0.871 & 8.328 \\
\hline $\begin{array}{l}\text { My business unit is regarded as an IT leader in our industry for supply chain } \\
\text { communication system ( } \mathrm{Wu} \text { et al. 2006) }\end{array}$ & In our industry, our company is regarded as an IT leader for export management & 0.625 & 3.205 \\
\hline \multicolumn{4}{|l|}{ Export performance $(\mathrm{CR}=0.9392)$} \\
\hline \multicolumn{4}{|l|}{ How satisfied are you with the results of your exporting activities? } \\
\hline Export sales growth (Katsikeas, Leonidou, and Morgan 2000) & & 0.882 & 37.706 \\
\hline Export sales volume (Katsikeas, Leonidou, and Morgan 2000) & & 0.917 & 61.295 \\
\hline $\begin{array}{l}\text { Contribution of exporting to profits (Katsikeas, Leonidou, and Morgan } \\
2000 \text { ) }\end{array}$ & & 0.806 & 16.473 \\
\hline Export market share (Katsikeas, Leonidou, and Morgan 2000) & & 0.834 & 21.042 \\
\hline Overall export performance (Katsikeas, Leonidou, and Morgan 2000) & & 0.903 & 49.961 \\
\hline
\end{tabular}

* 7-point Likert Scale (strongly disagree $=1$; strongly agree $=7$ )

** items taken directly from the interview transcripts (Forbes 2006) F=Firm and L=Lines (of the interview transcript) 
Table 3: Company characteristics organised by industry and born-globalness of firms

\begin{tabular}{|l|l|c|c|c|c|c|}
\hline Industry & $\begin{array}{l}\text { Born- } \\
\text { globalness }\end{array}$ & $\begin{array}{c}\text { Internet } \\
\text { experience } \\
\text { (in years) } \\
\text { Mean }\end{array}$ & $\begin{array}{c}\text { Firm age } \\
\text { (in years) } \\
\text { Mean }\end{array}$ & $\begin{array}{c}\text { Export } \\
\text { experience } \\
\text { (in years) } \\
\text { Mean }\end{array}$ & $\begin{array}{c}\text { Export } \\
\text { ratio (\%) } \\
\text { Mean }\end{array}$ & $\begin{array}{c}\text { Revenue (in } \\
\text { million £) } \\
\text { Mean }\end{array}$ \\
\hline \multirow{2}{*}{ Low-tech } & Non-BG & Mean & Mean & Mean & Mean & Mean \\
\cline { 2 - 7 } & $B G$ & 9 & 47 & 28 & $32.99 \%$ & 10.70 \\
\hline High-tech & Non-BG & 11 & 29 & 24 & $48.80 \%$ & 11.85 \\
\cline { 2 - 7 } & $B G$ & 11 & 31 & 29 & $32.22 \%$ & 16.66 \\
\hline
\end{tabular}

Table 4: Company characteristics

\begin{tabular}{|c|c|c|c|}
\hline \multicolumn{2}{|l|}{ Dimension } & \multirow{2}{*}{$\begin{array}{r}\text { Number } \\
\text { of firms } \\
58\end{array}$} & \multirow{2}{*}{$\begin{array}{r}\text { Percentage } \\
\text { of firms } \\
50.43 \%\end{array}$} \\
\hline Born- & $B G$ & & \\
\hline globalness & non-BG & 57 & $49.57 \%$ \\
\hline \multirow[t]{2}{*}{ Industry } & Low-tech & 54 & $46.96 \%$ \\
\hline & High-tech & 61 & $53.04 \%$ \\
\hline \multirow[t]{4}{*}{ Employees } & $1-9$ & 2 & $1.74 \%$ \\
\hline & $10-49$ & 27 & $23.48 \%$ \\
\hline & $50-149$ & 63 & $54.78 \%$ \\
\hline & $150-250$ & 22 & $19.13 \%$ \\
\hline \multirow[t]{5}{*}{ Export ratio } & $<10 m$ & 13 & $11.30 \%$ \\
\hline & $10-24.99 \mathrm{~m}$ & 18 & $15.65 \%$ \\
\hline & $25-49.99 m$ & 33 & $28.70 \%$ \\
\hline & $50-74.99 \mathrm{~m}$ & 30 & $26.09 \%$ \\
\hline & $>75 m$ & 19 & $16.52 \%$ \\
\hline \multirow[t]{5}{*}{ Revenue } & $1.00<1 \mathrm{~m}$ & 2 & $1.74 \%$ \\
\hline & $2.001 m-4.99 m$ & 21 & $18.26 \%$ \\
\hline & $3.005 m-9.99 m$ & 31 & $26.96 \%$ \\
\hline & $4.0010 m-24.99 m$ & 36 & $31.30 \%$ \\
\hline & $5.0025 m-50 m$ & 19 & $16.52 \%$ \\
\hline
\end{tabular}


Table 5: Overall model evaluation

\begin{tabular}{|l|c|c|r|r|r|}
\hline & AVE & $\begin{array}{c}\text { Highest } \\
\text { squared } \\
\text { correlation }\end{array}$ & $\begin{array}{l}\text { Composite } \\
\text { Reliability }\end{array}$ & $\begin{array}{c}\text { Cranach's } \\
\text { Alpha }\end{array}$ & R Square \\
\hline alt.phys. presence & 0.5946 & 0.10896601 & 0.7193 & 0.7671 & 0 \\
\hline cost reduction & 0.9106 & 0.41615401 & 0.9806 & 0.9736 & 0 \\
\hline communication & 0.4618 & 0.32455809 & 0.7704 & 0.6636 & 0 \\
\hline $\begin{array}{l}\text { reaching new } \\
\text { customers }\end{array}$ & 0.7379 & 0.15031129 & 0.8491 & 0.6469 & 0 \\
\hline export management & 0.6756 & 0.06120676 & 0.9113 & 0.8855 & 0 \\
\hline market research & 0.7322 & 0.41615401 & 0.9303 & 0.9396 & 0.9187 \\
\hline performance & 0.7560 & 0.06120676 & 0.9392 & 0.3447 \\
\hline $\begin{array}{l}\text { relationship } \\
\text { building }\end{array}$ & 0.5268 & 0.32455809 & 0.8086 & 0.7014 & 0 \\
\hline
\end{tabular}

Table 6: Control variables

\begin{tabular}{|c|c|c|c|c|c|c|c|c|c|}
\hline & & \multicolumn{8}{|c|}{ Control variables } \\
\hline & & \multicolumn{2}{|c|}{ Born globalness } & \multicolumn{2}{|c|}{ Industry } & \multicolumn{2}{|c|}{$\begin{array}{c}\text { Export experience } \\
\text { (export ratio) }\end{array}$} & \multicolumn{2}{|c|}{$\begin{array}{c}\text { Internet experience } \\
(y r s)\end{array}$} \\
\hline & $\begin{array}{l}\text { full } \\
\text { sample }\end{array}$ & $B G$ & non- $B G$ & $\begin{array}{l}\text { low- } \\
\text { tech }\end{array}$ & $\begin{array}{l}\text { high- } \\
\text { tech }\end{array}$ & less $50 \%$ & $\begin{array}{l}\text { more } \\
50 \%\end{array}$ & $\begin{array}{l}<10 \\
y r s\end{array}$ & $>10 y r s$ \\
\hline $\begin{array}{l}\text { Export } \\
\text { performance }\end{array}$ & $\begin{array}{c}\mathrm{N}=115 \\
\mathrm{R}^{2}=0.345\end{array}$ & $\begin{array}{c}\mathrm{N}=58 \\
\mathrm{R}^{2}=0.382\end{array}$ & $\begin{array}{c}\mathrm{N}=57 \\
\mathrm{R}^{2}=0.141\end{array}$ & $\begin{array}{c}\mathrm{N}=54 \\
\mathrm{R}^{2}=0.284\end{array}$ & $\begin{array}{c}\mathrm{N}=61 \\
\mathrm{R}^{2}=0.256\end{array}$ & $\begin{array}{c}\mathrm{N}=65 \\
\mathrm{R}^{2}=0.730\end{array}$ & $\begin{array}{c}\mathrm{N}=50 \\
\mathrm{R}^{2}=0.434\end{array}$ & $\begin{array}{c}\mathrm{N}=46 \\
\mathrm{R}=0.292\end{array}$ & $\begin{array}{c}\mathrm{N}=69 \\
\mathrm{R}^{2}=0.104\end{array}$ \\
\hline Communication & $-0.223 *$ & $-0.386^{*}$ & -0.063 & 0.064 & -0.170 & 0.049 & -0.053 & 0.122 & -0.014 \\
\hline Cost reduction & 0.082 & 0.009 & -0.017 & 0.163 & -0.120 & 0.042 & -0.033 & -0.124 & -0.021 \\
\hline $\begin{array}{l}\text { Reaching new } \\
\text { customers }\end{array}$ & $0.164 *$ & 0.238 & 0.143 & 0.082 & 0.146 & 0.061 & -0.055 & -0.010 & 0.117 \\
\hline $\begin{array}{l}\text { Adv. export } \\
\text { management } \\
\text { technology }\end{array}$ & $0.264 *$ & 0.183 & 0.210 & 0.109 & 0.189 & $-0.556 *$ & $0.172 *$ & 0.019 & -0.009 \\
\hline Market research & 0.091 & 0.141 & -0.024 & -0.125 & 0.276 & 0.034 & -0.007 & 0.194 & -0.028 \\
\hline $\begin{array}{l}\text { Alternative } \\
\text { physical } \\
\text { presence }\end{array}$ & $-0.360 *$ & -0.238 & 0.260 & 0.464 & -0.290 & $-0.638 *$ & $0.688 *$ & -0.291 & 0.274 \\
\hline $\begin{array}{l}\text { Relationship } \\
\text { building }\end{array}$ & $-0.183^{a}$ & -0.116 & -0.043 & -0.078 & -0.078 & 0.040 & 0.064 & -0.201 & -0.111 \\
\hline
\end{tabular}

*... significant at the 0.05 level.

a... significant at the 0.10 level 
Figure 1: Conceptual Framework

Internet deployment capabilities

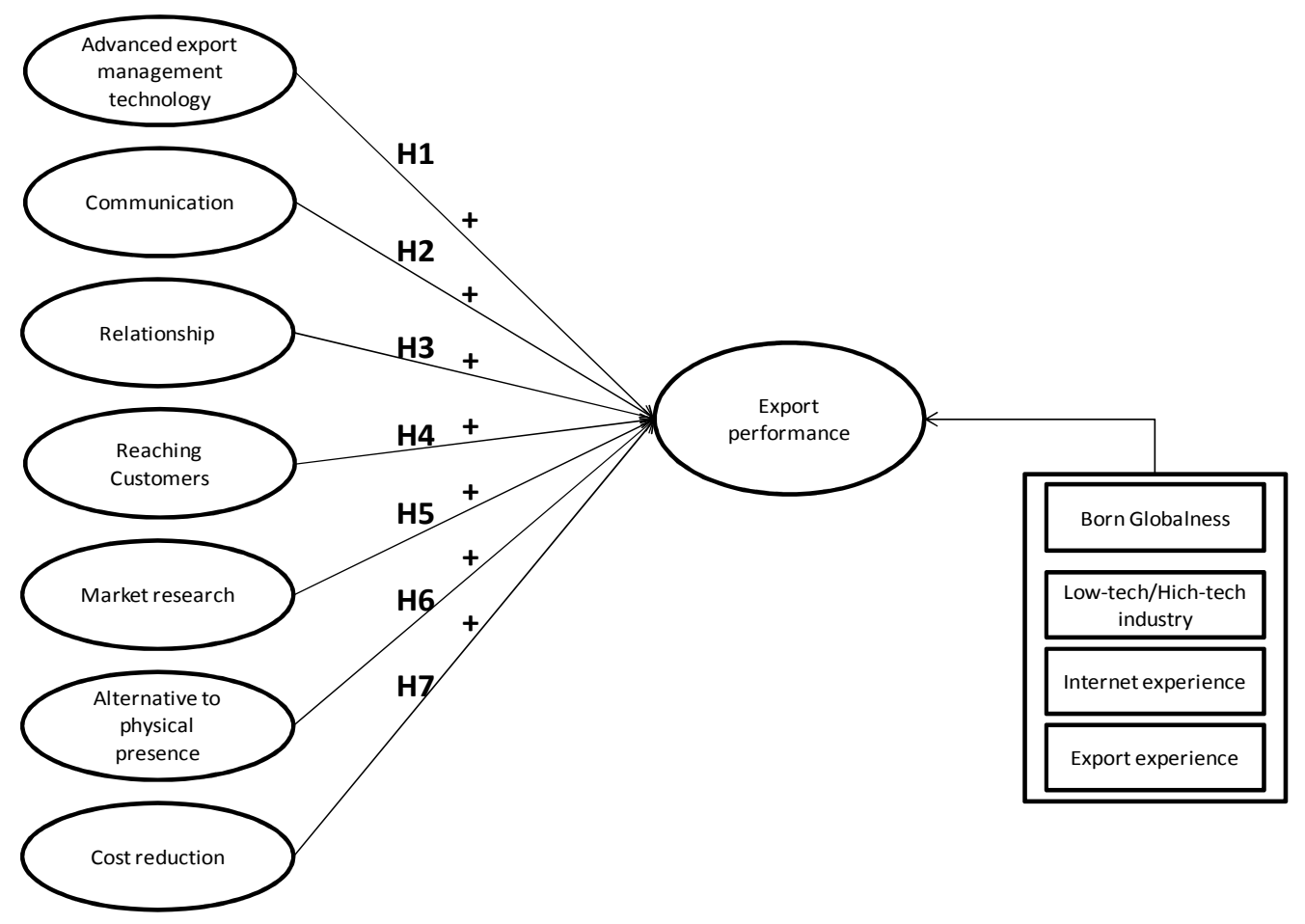


Figure 2: Results of the PLS structural model for $N=115$

Internet deployment

Performance

Controlvariables capabilities

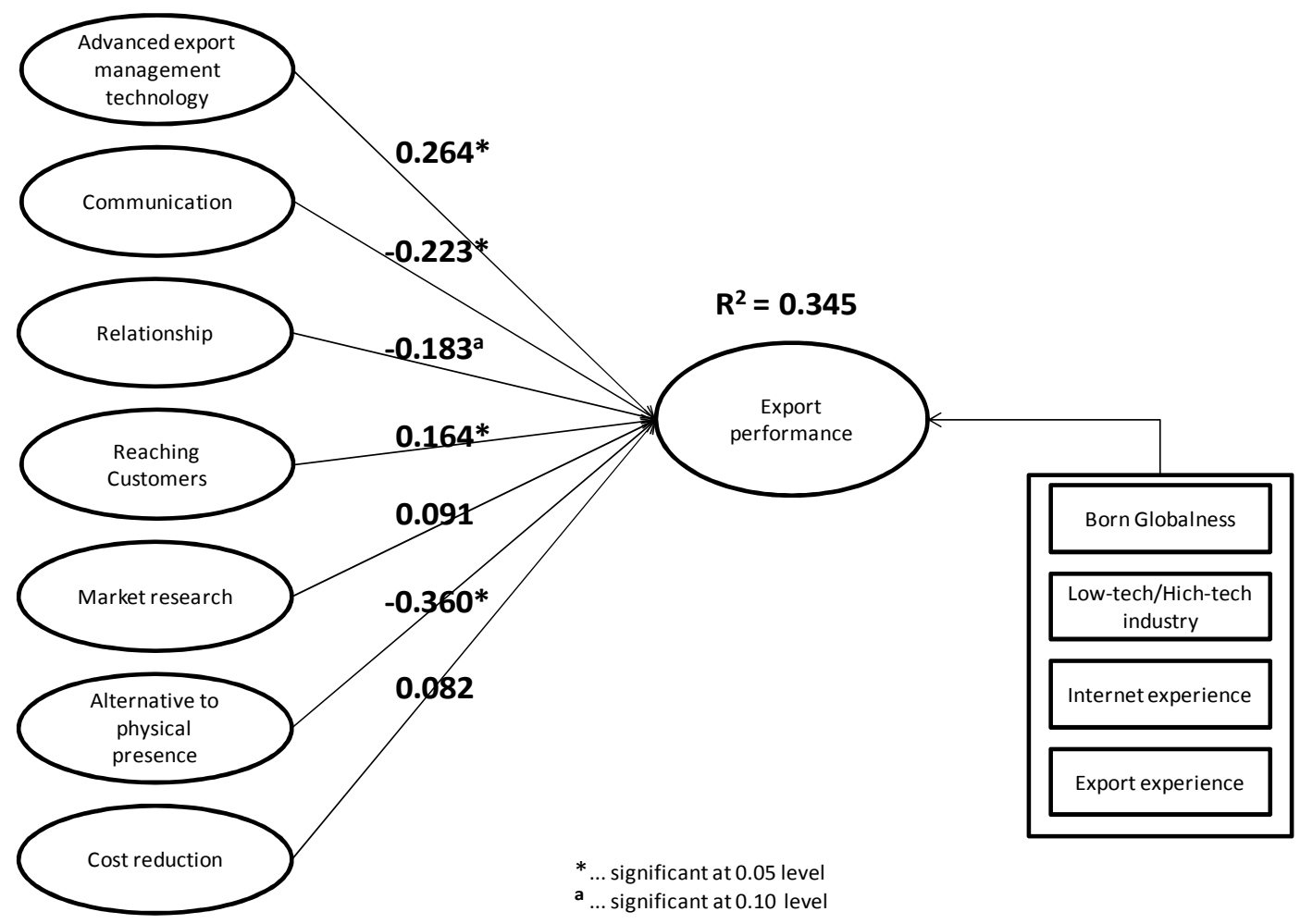

